\title{
Word Decoding Abilities of 1st Graders with Developmental Dyslexia Considering Reading Severity and Word and Syllable Structure
}

\author{
Haerim $\mathrm{Yu}^{\mathrm{a}}$, Hyoeun Won ${ }^{\mathrm{a}}$, Soyeong Pae ${ }^{\mathrm{b}}$ \\ ${ }^{a}$ Department of Speech-Language Pathology and Audiology, Graduate School of Hallym University, Chuncheon, Korea \\ ${ }^{b}$ Division of Speech pathology and Audiology, Institute of Audiology \& Speech Pathology, Hallym University, Chuncheon, Korea
}

Correspondence: : Soyeong Pae, $\mathrm{PhD}$ Division of Speech Pathology and Audiology, Institute of Audiology \& Speech Pathology, Hallym University, 1 Hallimdaehak-gil, Chuncheon 24252, Korea

Tel: +82-33-248-2214

Fax: +82-33-256-3420

E-mail: spae@hallym.ac.kr

Received: July 5, 2021

Revised: August 5, 2021

Accepted: August 5, 2021
Objectives: This study investigated word decoding abilities of 1st graders with Developmental dyslexia according to the level of decoding difficulty, meaning availability, word and syllable structure. Methods: Twenty Korean 1st graders with developmental dyslexia participated in 40 word-reading tasks individually. All of them had severe decoding difficulties, even with normal listening comprehension (KORLA; Pae et al., 2015) and intelligence (K-CTONI-2; Park, 2014). The group differences by decoding difficulties were compared considering the meaning of words, the number of syllable-final graphemes, and the position of each grapheme in a syllable. Results: Both the severe and less-severe group in Korean word-decoding difficulties revealed the gaps between word reading and nonword reading. Both groups had decoding difficulties when a word had syllable-final graphemes, while the severe group had even lower performances in word readings with 2 syllable-final graphemes. Both groups showed similar performances in reading syllable-initial graphemes while the severe group had lower performances both in reading syllable-medial vowel graphemes and syllable-final consonant graphemes compared to the less-severe group. Conclusion: Korean 1st graders with developmental dyslexia seemed to be in urgent need of decoding support considering word and syllable structure. Triggering the non-lexical route with non-words considering the grain size of syllable-medial vowel graphemes and syllable-final graphemes would facilitate word decoding abilities of severely dyslexic Korean children.

Keywords: Korean, Developmental dyslexia, Severity of decoding difficulties, Grain size of syllable-final graphemes
DSM-5 (American Psychiatric Association, 2013)에서는 특정학 습장애(Specific Learning Disorder)의 하위유형으로 난독증(dyslexia)은 단어를 정확하고 유창하게 읽어내는 것에 어려움을 보이 거나, 철자법 및 쓰기능력 부진을 가진다고 정의하였다. 읽기의 궁 극적인 목표인 읽기 이해(reading comprehension)를 위해서는 글 자와 소리를 대응하여 읽어내는 해독(decoding)능력과 언어적 이 해능력(language comprehension)이 필요하다(simple view of reading, SVR; Gough \& Tunmer, 1986). 하지만 난독증을 가진 아동은 읽기 이해의 필수적인 능력인 단어 해독에서부터 어려움을 보여 향
후 학습에 어려움을 가지게 된다.

난독 아동의 단어 해독 어려움은 언어적 요소인 음운론적 결함 에 의해 나타난다고 한다(Catts, 1996; Hogan, 2018; Lyon, Shaywitz, \& Shaywitz, 2003). 난독증을 가진 아동이 보이는 음운론적 결함은 음운론적 정보를 표상하고 사용하는 것에 어려움을 보이 는 것으로, 음운론적 정보를 구어 및 문어 처리 과정에서 사용하는 것을 음운처리(phonological processing)라고 한다(Wagner \& Torgesen, 1987). 음운처리는 음운인식(phonological awareness), 빠른 자 동이름대기를 의미하는 어휘적 접근에서의 음운 재부호화(pho- 
nological recoding in lexical access), 음운기억을 의미하는 작업기 억에서의 음운 재부호화(phonetic recoding in working memory) 로 나누어 살펴볼 수 있으며, 이는 읽기능력에 영향을 미치는 요인 이라고 한다. 다수의 국내 연구에서는 음운처리능력이 학령전기 뿐 만 아니라 학령기에 들어가는 아동에서도 발달한다고 보고하였으 며, 읽기능력에 영향을 미친다는 결과를 보였다(Kim \& Kim, 2009; Kim \& Pae, 2007; Kim, Yoo, \& Kim, 2010).

읽기의 이중 경로 모델(Dual-Route Model; Ziegler et al., 2008)에 따르면 단어 해독 과정을 어휘경로(lexical-route)와 비어휘경로(non lexical-route)로 나누어 살펴볼 수 있다고 한다. 초기 해독 발달에 서는 어휘경로를 사용하여 읽기도 하지만, 주로 자소와 음소를 일 대일 대응하여 읽는 비어휘경로를 사용하게 된다. 발달성 난독증 아동의 경우 음운론적 결함으로 인해 글자와 소리를 대응하는 것 에 어려움을 가지고(Peterson \& Pennington, 2015; Snowling, 1998), 그 결과 비어휘경로로 읽는 것에 어려움을 가지게 되어 무의미 단 어 및 비친숙한 단어 읽기에 어려움을 겪게 된다.

난독증을 가진 아동이라고 하여 모두 동일한 수준의 읽기 어려 움을 가지는 것은 아니다. 다수의 국외 연구에서는 난독 아동의 넓 은 읽기 수행능력의 차이를 고려하여 심도(severe) 그룹과 중도(moderate) 그룹으로 나누어 출현율의 차이를 밝혔다(Chan, Ho, Tsang, Lee, \& Chung, 2007; Miles, 2004). Torgesen (2005)에서도 난독 아 동을 심도(severe) 집단과 중도(moderate) 집단으로 나누었으며, 백 분위수 2 미만에 속하는 아동을 심도 집단, 백분위수 10 미만에 속 하는 아동을 중도 집단으로 정의하였다. 국내 연구에는 초등 1학년 일반 학급 학생의 읽기 수행을 상, 중, 하로 나누어 3월에서 7월에 걸친 읽기 발달 양상을 살펴보거나(Jeong, 2014), 난독 아동을 언어 및 다른 능력에 따라 분류를 시도한 연구가 있다(Lee \& Kim, 2020). 하지만 난독 집단을 읽기 수행능력에 따라 나누어 각 하위 집단에 서의 읽기 특성을 살펴본 연구가 아직 없는 실정이다. 난독 아동을 대상으로 한 국내 연구들을 살펴보았을 때, 난독 집단 내의 읽기 점 수 편차가 큰 것으로 보아 같은 난독 집단에 속하더라도 읽기 수행 력의 범위가 넓다는 것을 알 수 있다(Kim, 2015; Pae, Shin, \& Seol, 2017; Yang \& Pae, 2018). 따라서 국내 난독 아동을 읽기 수행력에 따라 나누어 보고, 단어 해독 특성이 어떠한지 알아볼 필요가 있다.

Chall (1983)의 읽기 발달을 살펴보면 학령전기에 문해사회화가 발달하고, 초등 1-2학년 시기에 자소와 음소를 대응하는 규칙을 습 득하여 단어를 읽을 수 있게 된다고 한다. 이 시기에는 어휘경로 (lexical-route)를 사용하여 고빈도 단어나음운적으로 규칙적인 단 어를 읽을 수 있게 되고, 자소와음소를 대응하는 규칙을 사용하여 읽는 음성음운단계에 들어서게 되어 비어휘경로도 함께 사용하게
된다. 한글은 영어와 달리 자소와 음소 대응 관계가 투명한 표층표 기체계(transparent orthography)로, 단어 읽기 발달이 영어를 사용 하는 아동들에 비해 이른 시기에 이루어진다고 보고되었다(Frith, Wimmer, \& Landerl, 1998; Landerl, Wimmer, \& Frith, 1997). 따라 서 유치원과 초등학교 저학년을 대상으로, 단어를 의미 유무(Byun \& Kim, 2008; Kim \& Pae, 2007, 2011; Yoon, Kim, \& Pae, 2011), 자 소-음소 일치 유무(Jeong, 2017; Kim, 2015; Kim \& Pae, 2007, 2011; Song, Shin, \& Pae, 2016; Yoon et al., 2011), 받침의 개수에 따른 단 어 구조, 음절 내 위치(Jeong, 2017; Yang \& Pae, 2018) 등으로 세분 화하여 단어 읽기 특성을 살펴보는 연구들이 활발히 이루어졌다.

Kim과 Pae (2007) 연구에서는 한국어를 사용하는 일반 유치원 아동을 대상으로 자소와음소가 일치하는 단어 50 개(의미 단어 25 개, 무의미 단어 25개)를 읽도록 하였다. 그 결과 의미 단어의 경우 $97.2 \%$ 의 정확률을 보인데 반해 무의미 단어의 경우 $85.6 \%$ 의 정확 률을 보여 유의미한 차이가 나타났다. 초등학교 1학년 발달성 난독 아동을 대상으로 자소와 음소가 일치하는 의미 단어와 무의미 단 어의 읽기 수행능력 차이를 살펴본 Yang과 Pae (2018)의 연구에서 도 의미 유무에 따른 단어 읽기 수행능력 차이가 유의미한 것으로 나타났다. 따라서 단어 읽기의 초기단계에 속해 있거나 어려움을 보이는 아동의 경우, 단어 읽기 능력이 단어의 의미 유무에 따라 차 이가 나타날 수 있음이 확인되었다. 그러나 Yan과 Pae (2018)의 연 구에서 발달성 난독 아동 집단의 단어 읽기능력이 평균 66.28(\%), 표준편차 18.24임을 고려하였을 때, 다양한 해독 수행력의 발달성 난독 아동이 하나의 집단으로 정의되었다는 점에서 제한이 있다. 따라서 발달성 난독 아동 집단을 단어 해독 수행능력에 따라 세분 화하고, 단어의 의미 유무에 따른 단어 해독 특성의 차이를 살펴볼 필요가 있다.

한국어 단어 해독의 발달적 특성을 자소와 음소의 일치 유무에 따라 보았을 때, 일치형 단어가 불일치형 단어보다 발달적으로 선 행한다고 한다(Jeong, 2017; Kim, 2015; Kim \& Pae, 2007, 2011; Song et al., 2016; Yoon et al., 2011). 또한 초등 저학년 일반 아동의 경우, 일치형 단어를 거의 모두 읽어내어 천정점에 이르는 반면, 읽기 부 진 아동은 일치형 단어에서도 읽기에 어려움을 보이는 것으로 나 타났다. 한국어 읽기 검사의 해독 검사 중 자소와 음소가 일치하는 단어를 분석하여 개별화된 중재 목표를 적용한 Won, Seol, Jang, Lee와 Pae (2020)에서는 동일한 난독 고위험군 집단일지라도 대상 자마다 일치 단어를 읽을 때 보이는 오류 특성이 서로 다름을 보여 주었다. 따라서 단어 읽기 수행능력과 오류 특성에 따라 집단을 세 분화하여 살펴보는 것이 필요하다.

단어 해독 능력을 자세히 살펴보기 위해 단어 구조에 따른 읽기 
수행을 살펴볼 수 있다. 한국어의 단어는 음절로 구성되며, 음절은 중성 자소를 전후로 초성과 종성 자소 위치에 자음 자소가 배치된 다(Lee, 1998). 따라서 음절을 구성하는 자소의 개수, 또는 단어를 구성하는 음절의 개수에 따라 단어 구조의 복잡성이 달라질 수 있 다. 단어 구조에 따른 읽기 수행력을 살펴본 국내 연구들은 단어 내 에 위치하는 종성의 개수와 위치를 달리하여 'CV-CV, CV-CVC, CVC-CV, CVC-CVC (C: consonant, V: vowel)' 구조를 가진 단어 를 제시하였고, 이에 따른 해독 수행력 차이를 확인하였다(Jeong, 2017; Yang \& Pae, 2018). Jeong (2017)은 초등 1학년 아동들을 대상 으로 받침이 없는 단어와 받침이 포함되어 있으나 자소와 음소가 일치하는 단어를 읽도록 하였는데, 받침이 있는 단어에서의 읽기 오류가 더 많이 나타난다고 보고하였다. Yang과 Pae (2018)에서는 초등 1 학년 일반 아동의 경우 받침 개수에 따라 읽기 수행력에 차 이가 나타나지 않았으나, 발달성 난독 고위험군 아동은 받침이 없 는 단어에서 $82 \%$, 받침이 1 개 포함된 단어에서 $81 \%$, 받침이 2 개 포 함된 단어에서 $57 \%$ 의 정확도를 보여 받침의 개수가 많아질수록 단 어 해독에 어려움을 보인다는 것을 확인하였다.

아동의 단어 읽기능력에 따라 오류가 나타나는 음절 내 위치가 다르다는 것도 선행연구에서 확인되었다. Yang과 Pae (2018)에서는 초등 1 학년 일반 아동의 경우, 초성 자소 $99 \%$, 중성 자소 $99 \%$, 종성 자소 $95 \%$ 의 정확도로 읽어내어 음절 내 위치에 따른 단어 해독 수 행력의 차이가 나타나지 않았다. 그러나 발달성 난독 고위험군 아 동의 경우 초성 자소 $80 \%$, 중성 자소 $82 \%$, 종성 자소 $70 \%$ 의 정확 도를 보여 음절 내 위치 중 특히 종성 자소에서 읽기 어려움이 나타 났다. 또한 초등 1,2 학년 난독 고위험군 아동을 대상으로 단어 해 독 중재 효과를 살펴본 Won 등(2020)에 참여한 대상자들의 읽기 특성을 보았을 때, 중성 자소 $90.57 \%$, 초성 자소 $88.41 \%$, 종성 자소 $77.35 \%$ 로 확인되어 종성 자소 위치에서 가장 어려움을 보이는 것 으로 나타났다.

선행연구들을 종합해보면, 발달성 난독 아동은 동일한 난독 집 단에 속하더라도 개인의 읽기능력에 대한 스펙트럼이 넓고(Chan et al., 2007; Miles, 2004; Torgesen, 2005) 단어의 의미 유무, 단어구 조 및 자소의 음절 내 위치에 따른 해독 오류 양상이 다양하다. 하 지만 아직까지 난독 아동의 단어 읽기능력을 심도에 따라 집단을 나누어 읽기 수행을 살펴보거나 읽기 오류 특성을 살펴본 연구는 찾아보기 어렵다. 따라서 본 연구에서는 읽기의 기초 능력인 해독 능력이 발달하는 초등 1 학년 발달성 난독 아동을 해독 수행력에 따라 심도 난독 집단(Severe dyslexia group)과 경심도 난독 집단 (Less severe dyslexia group)으로 나누어 자소와 음소가 일치하는 단어에서 의미 유무, 단어구조 및 음절 내 위치에 따라 어떠한 단어
해독수행을 보이는지 알아보고자 한다.

\section{연구방법}

\section{연구대상}

본 연구에는 강원도 난독 고위험군 선별을 위한 선별검사에서 미통과하여 심화검사에 의뢰된 초등 1 학년 발달성 난독 아동 20 명 이 속하였다. 평가는 1학기 말에서 2학기 초에 실시하였으며, 읽기 및 쓰기 관련 치료력이 없는 아동으로 선정하였다. 대상자는 모두 한국어 읽기검사(KOLRA; Pae, Kim, Yoon, \& Jang, 2015) 핵심검사 의 읽기지수 1 (해독, 읽기이해)이 표준점수 평균 $56.95(\mathrm{SD}=11.04)$ 로 읽기에서 어려움을 보이며, 듣기이해검사에서 표준점수 평균 103.58 (SD = 11.16)로 담화 듣기 이해력이 또래 수준에 속하는 아 동이었다. 또한 한국 비언어성 지능검사(K-CTONI-2; Park, 2014) 도형척도에서 지능지수 평균 $102.5(\mathrm{SD}=12.35)$ 로 정상 범주의 지 능을 보이며 담임 교사, 부모에 의해 기타 발달 및 감각, 주의력상의 문제가 없다고 보고된 아동이었다.

연구에 참여한 전체 대상자는 KOLRA의 하위검사인 단어 해독 점수가 백분위수 4 미만에 속하여 또래 대비 읽기에 큰 어려움을 보 이는 학생들이다. 해독 수준에 따라 심도 난독 집단(Severe Dyslexia Group) 10명, 경심도 난독 집단(Less Severe Dyslexia Group) 10 명으로 나누었다. 해독 수준은 Torgesen (2005)을 참고하여 백분위 수 1미만인 아동을 심도 난독 집단(표준점수 $\mathrm{M}=41.20, \mathrm{SD}=6.94$ ), 백분위수 1-4인 아동을 경심도 난독 집단(표준점수 $\mathrm{M}=69.40$, $\mathrm{SD}=3.30$ )으로 정의하였다. 연구에 참여한 대상의 자세한 정보는 Table 1과 같다.

\section{연구절차}

본 연구는 강원도 난독 학생 지원 사업에 참여한 문해 전문 언어 재활사 5 명이 각 아동의 학교에 방문하여 독립적인 공간에서 1 대 1

Table 1. Participants' characteristics

\begin{tabular}{lccc}
\hline & $\begin{array}{c}\text { Severe dyslexia group } \\
(\mathrm{N}=10)\end{array}$ & $\begin{array}{c}\text { Less severe dyslexia } \\
\text { group }(\mathrm{N}=10)\end{array}$ & t-value \\
\hline K-CTONI-2 & $105.4(12.48)$ & $99.40(11.51)$ & 1.117 \\
KOLRA (LRO1) $^{a}$ & $48.00(5.65)$ & $67.60(3.47)$ & $-9.339^{*}$ \\
Decoding score $^{b}$ & $41.20(6.94)$ & $69.40(3.30)$ & $-11.599^{*}$ \\
KOLRA (LCS) $^{c}$ & $100.8(10.65)$ & $106.7(11.41)$ & -1.195 \\
\hline
\end{tabular}

Values are presented as mean (SD).

aLR01 = Language reading quotient $1,{ }^{b}$ Decoding score=Decoding standard score, ${ }^{\complement} \mathrm{LCS}=$ Listening comprehension standard score.

${ }^{*} p<.05$. 
로 검사를 실시하였다. 검사는 약 1 시간에서 1 시간 30 분 정도 소요 되었다. 연구에 사용된 검사도구는 한국어 읽기검사(KOLRA; Pae et al., 2015)의 하위 검사인 단어 해독 검사에서 자소-음소 일치형 단어 40 개를 사용하였고(의미 단어 20 개, 무의미 단어 20 개), 아동 에게 2음절 낱말이 적힌 글자판을 보여주며 읽도록 하였다. 아동이 읽은 단어는 평가 진행 후 3 일 내에 전사를 진행하였으며, 단어의 의미 유무, 단어구조와음절 내 위치에 따라 분석하였다. 채점자 간 분석 신뢰도를 확인한 결과, 전체 자료에 대한 분석 신뢰도는 $100 \%$ 일치하였다. 채점 및 분석 방법은 아래와 같으며 자세한 반응 예시 는 Appendix 1, 2에 제시하였다.

\section{의미 유무에 따른 해독 특성}

단어의 의미 유무에 따른 해독 특성을 살펴보기 위해 단어 해독 검사에서 사용한 자소-음소 일치형 의미 단어 20 개와 무의미 단어 20 개로 나누어 분석하였다. 본 연구에서 사용한 한국어 읽기검사 (KOLRA; Pae et al., 2015)는 1학년에서 6학년까지를 대상으로 하 는 검사이므로 본 연구의 분석에 사용된 의미 단어의 일부는 1 학 년 아동들에게 의미를 모르는 무의미 단어일 가능성이 있다. 따라 서 국립국어원에서 연구된 초등학교 교과서 어휘 분석(Kim, 2010) 을 근거로 하여 저학년(1-3학년) 교과서에 수록된 단어만을 포함하 여 의미 단어 총 18 개를 분석하였다. 무의미 단어는 의미 단어와 동 일한 음절구조를 가진 단어 18 개를 선정하여 분석하였다. 아동이 정확하게 읽은 단어는 1 점, 정확하게 읽지 못한 단어는 0 점으로 채 점되었으며, 최소 0 점에서 최대 36 점을 받을 수 있었다. 의미 단어 및 무의미 단어별로 정확하게 읽은 문항 수를 의미 단어, 무의미 단 어 각각 총수로 나눈 후 100 을 곱하여 백분율(\%)을 산출하였다.

\section{단어구조에 따른 해독 특성}

단어구조에 따른 해독 특성을 살펴보기 위해 단어 해독 검사에 서 사용한 자소-음소 일치형 단어 40 개를 4 가지의 유형으로 나누었 다. 단어구조는 CV-CV(10), CV-CVC(6), CVC-CV(9), CVC-CVC(15) 로 나누었으며, 각 단어구조별로 읽기 정확률을 산출했다. 아동이 정확하게 읽은 문항은 1 점, 정확하게 읽지 못한 단어는 0 점으로 채 점되었으며, 최소 0 점에서 최대 40 점을 받을 수 있었다. 각 단어구 조별로 아동이 정확하게 읽은 문항 수를 단어구조별 총 문항 수로 나눈 후 100 을 곱하여 백분율(\%)로 산출하였다.

\section{음절 내 위치에 따른 해독 특성}

음절 내 위치에 따른 해독 특성을 살펴보기 위해 단어 해독 검사 에서 사용한 자소-음소 일치형 단어 40 개를 자소 단위(초성 자소,
중성 자소, 종성 자소)로 분석하였다. 아동이 정확하게 읽은 자소 는 1 점, 정확하게 읽지 못한 자소는 0 점으로 채점하였다. 초성과 중 성 자소는 각각 총 80 개로 최소 0 점에서 최대 80 점을 받을 수 있었 으며, 종성 자소의 경우 총 45 개로 최소 0 점에서 최대 45 점을 받을 수 있었다. 음절 내 위치별로 아동이 정확하게 읽은 자소 수를 음절 내 위치별 총 자소 수로 나눈 후 100 을 곱하여 백분율(\%)로 산출하 였다. 또한 자소-음소 대응 능력을 살펴보기 위해 의미 대치 오류를 보인 문항은 분석에서 제외하였다(예: 시지 $\rightarrow /$ 시계/, 교장 $\rightarrow /$ 교실/).

\section{통계처리}

해독 수행능력과 단어의 의미 유무에 따른 해독 특성, 해독 수행 능력과 단어구조에 따른 해독 특성, 해독 수행능력과 음절 내 위치 에 따른 해독 특성을 살펴보고자 일요인이 반복 측정된 이원분산 분석(repeated two-way ANOVA)을 3 회 실시하였다. 상호작용효과 가 나타난 경우, 집단 간 차이를 살펴보기 위해 독립표본 $t$-검정(independent t-test)으로 사후분석을 실시하였으며, 집단 내 차이는 대응표본 $t$-검정(paired $t$-test)을 이용하여 사후분석을 하였다. 모 든 통계처리는 SPSS 25.0 을 사용하였다.

\section{연구결과}

\section{해독 수행능력과 의미 유무에 따른 해독 특성}

해독능력과 단어의 의미 유무에 대한 반복측정 이원분산분석을 실시한 결과, 해독능력 $\left(F_{(1,18)}=52.482, p=.000\right)$ 과 의미 유무 $\left(F_{(1,18)}=\right.$ $84.981, p=.000)$ 에 따른 주효과가 유의미하였고, 해독능력과 의미 유무 간 상호작용효과는 유의미하지 않았다 $\left(F_{(1,18)}=.062, p=.806\right)$ (Figure 1).

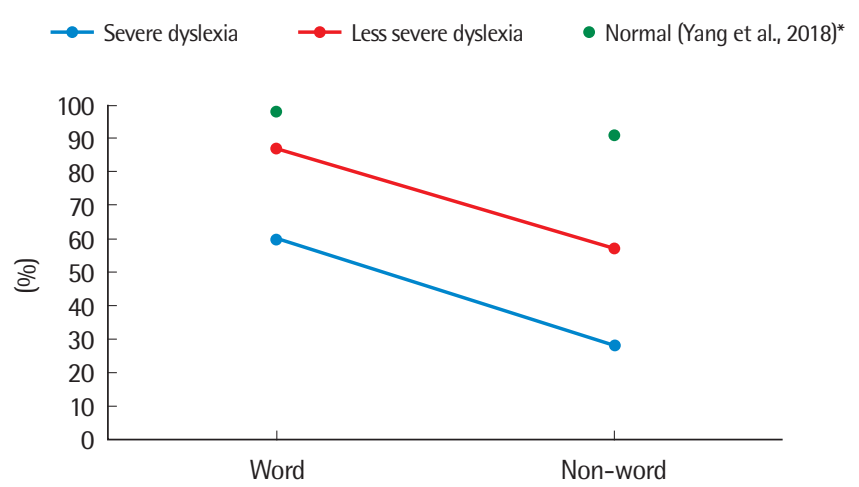

Figure 1. Decoding ability considering reading severity and meaning accessibility.

* Reading ability of typically developing 1st graders considering meaning accessibility. 


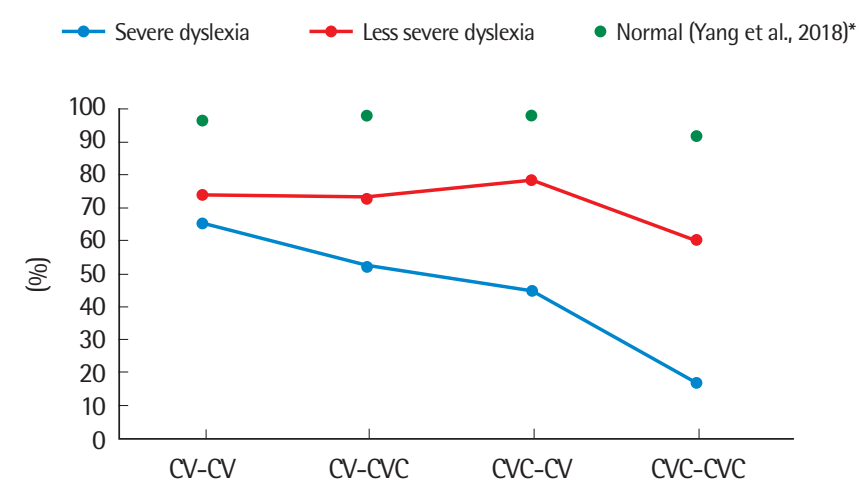

Figure 2. Decoding ability considering reading severity and word structure. * Reading ability of typically developing 1 st graders considering word structure.

\section{해독 수행능력과 단어구조에 따른 해독 특성}

해독능력과 단어구조에 대한 반복측정 이원분산분석을 실시한 결과, 해독능력과 단어구조 간 상호작용효과 $\left(F_{(1,18)}=26.152, p=.000\right)$ 가 유의미하였고, 해독능력 $\left(F_{(1,18)}=51.821, p=.000\right)$ 과 단어구조 $\left(F_{(1,18)}=70.536, p=.000\right)$ 에 따른 주효과 또한 유의미하였다. 이에 대한 사후분석을 독립표본 $t$-검정으로 실시한 결과, $\mathrm{CV}-\mathrm{CVC}(t=$ -3.377, $p<.05)$, CVC-CV $(t=-5.941, p<.05)$, CVC-CVC $(t=-8.677$, $p<.05)$ 단어구조에서 경심도 집단과 심도 집단 간 차이가 유의미 하였다. 각 집단 내에서의 단어구조별 해독 수행력을 살펴보기 위 해 대응표본 $t$-검정을 실시한 결과, 경심도 집단에서는 $\mathrm{CV}-\mathrm{CV}$ 와 CVC-CVC $(t=2.543, p<.05), \mathrm{CVC}-\mathrm{CV}$ 와 CVC-CVC $(t=3.324$, $p<.05)$ 단어구조에서 유의미한 차이를 보였다. 심도 집단에서는 $\mathrm{CV}-\mathrm{CV}$ 와 CVC-CV $(t=2.983, p<.05), \mathrm{CV}-\mathrm{CV}$ 와 CVC-CVC $(t=$ $12.856, p<.05$ ) 단어구조에서 유의미한 차이가 나타났다(Figure 2).

\section{해독 수행능력과 음절 내 위치에 따른 해독 특성}

해독능력과 음절 내 위치에 대한 반복측정 이원분산분석을 실시 한 결과, 해독능력과 음절 내 위치 간 상호작용효과 $\left(F_{(1,18)}=11.059\right.$, $p=.004)$ 가 유의미하였고, 해독능력 $\left(F_{(1,18)}=13.530, p=.002\right)$ 과 음 절 내 위치 $\left(F_{(1,18)}=40.813, p=.000\right)$ 에 따른 주효과 또한 유의미하였 다. 이에 대한 사후분석을 독립표본 $t$-검정으로 실시한 결과, 중성 $(t=-2.944, p<.05)$, 종성 $(t=-3.682, p<.05)$ 자소 위치에서 경심도 집단과 심도 집단 간 차이가 유의미하였다. 각 집단 내에서의 음절 내 위치별 해독 수행력을 살펴보기 위해 대응표본 $t$-검정을 실시한 결과, 경심도 집단에서는 초성과 중성 $(t=-3.192, p<.05)$, 초성과 종 성 $(t=3.392, p<.05)$, 중성과 종성 $(t=4.756, p<.05)$ 자소에서 차이 가 나타났으며, 심도 집단에서는 초성과 종성 $(t=5.443, p<.05)$, 중

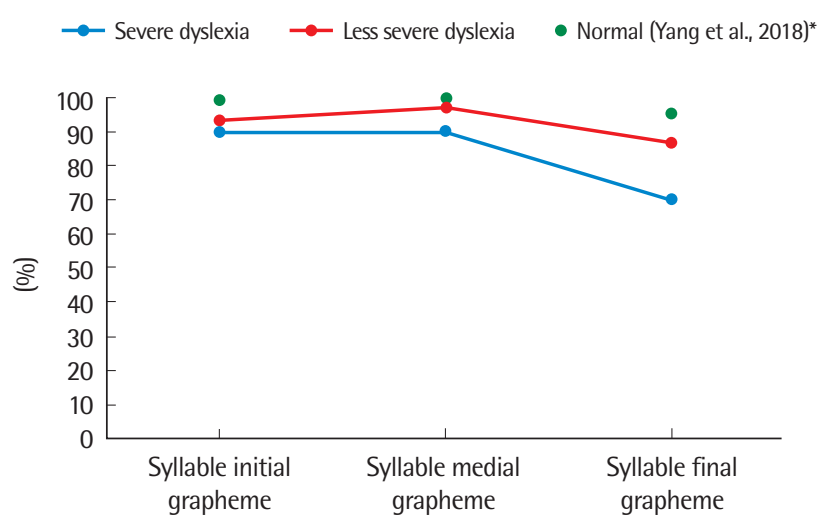

Figure 3. Decoding ability considering reading severity and syllable position. ${ }^{*}$ Reading ability of typically developing 1st graders considering syllable position.

성과 종성 $(t=4.854, p<.05)$ 자소에서 차이가 나타났다(Figure 3).

\section{논의 및 결론}

발달성 난독 아동은 읽기 수행 편차가 경도부터 심도까지 다양 하며 글자와 소리를 대응하여 읽는 것에 어려움을 가진다. 따라서 읽기의 이중경로 모델에서 비어휘경로를 사용하여 읽는 것에 어려 움을 가지며 무의미 및 비친숙 단어 읽기에 특히 어려움을 보일 수 있다(Ziegler et al., 2008). 본 연구에서 아동의 해독능력과 단어의 의미 유무에 따른 해독 특성을 살펴본 결과, 두 집단 모두 비어휘경 로를 활용해야 하는 무의미 단어에서 수행이 낮았으며 두 집단의 의미 단어와 무의미 단어에서의 수행력 격차 양상이 유사하여 상 호작용효과가 나타나지 않았다. 이러한 결과는 발달성 난독 아동 이 일반 아동에 비해 무의미 단어 읽기에 어려움을 보인다는 선행 연구 결과(Jeong, 2017; Kim \& Pae, 2011, 2014; Yang \& Pae, 2018) 를 지지한다. 또한 난독 집단 내에서 경심도의 읽기 어려움을 가진 아동이라도 자소와 음소를 대응하여 읽어야 하는 비어휘경로를 활용한 읽기에서 어려움이 두드러진다는 것을 시사한다. 본 연구와 동일한 읽기 과제를 실시한 Yang과 Pae (2018)에서 일반 아동 집단 의 경우, 의미 단어 읽기에서 수행력이 천정점에 도달하였다 $(\mathrm{M}=$ 98.05\%). 경심도 난독 집단의 경우, 초기 읽기 발달에서 나타나는 의미 단어 읽기가 어느 정도 가능한 것으로 보였으나 일반 집단에 비해 낮은 수행력을 갖는 것으로 나타났다 $(\mathrm{M}=87.22(\%), \mathrm{SD}=5.26)$. 하지만 무의미 단어에서는 두 집단 모두 일반 아동(Yang \& Pae, 2018: 약 91.10\%)에 비해 현저한 읽기 어려움을 보였다(Less Severe Group: $M=57.22$ (\%), $S D=15.05$, Severe Group: $M=28.33$ (\%), $\mathrm{SD}=10.29)$. 이를 통해 난독 집단을 읽기 수행력에 따라 나누어 살 
펴보았음에도 불구하고, 두 집단 모두 난독 집단이라는 공통된 특 징으로 인해 의미 단어 읽기 수행에 비해 무의미 단어 읽기에 매우 어려움을 보인다는 것을 알 수 있었다. 따라서 발달성 난독 아동에 대한 적절한 평가가 이루어지기 위해서는 비어휘 경로를 활용해야 하는 무의미 단어 및 비친숙 단어에서의 읽기 수행을 살펴보는 것 이 매우 중요함을 알수 있다.

발달성 난독 아동의 해독 수행력과 이음절 낱말에서의 한국어 단어구조에 따른 읽기 특성도 살펴보았다. 종성이 포함되지 않아 가장 단순한 구조를 갖는 CV-CV 구조(예: 보리, 가더)에서는 심도 난독 집단( $\mathrm{M}=65$ (\%), $\mathrm{SD}=14.33)$ 과 경심도 난독 집단 $(\mathrm{M}=74(\%)$, $\mathrm{M}=14.33)$ 간의 유의미한차이가 나타나지 않았다 $(t=-1.588, p=.130)$. 따라서 본 연구 과제가 실시된 초등학교 1학년 1학기 말과 2학기 초 에는 발달성 난독 아동이 일반 아동에 비해 수행력이 현저히 낮지 만, 받침이 없는 글자에 대해서는 심도 난독 집단과 경심도 난독 집 단 간의 수행에 유의미한 차이가 나타나지 않음을 확인하였다. 그 러나 두 집단은 단어에 종성 자소가 포함되어 $\mathrm{CV}-\mathrm{CVC}, \mathrm{CVC}-\mathrm{CV}$, CVC-CVC와 같은 복잡한 단어구조를 갖는 경우 유의미한 수행력 차이를 보였다. 심도 난독 집단의 경우 단어구조의 복잡성에 영향 을 많이 받아 단어에 종성 자소가 1 개라도 포함될 경우 읽기의 어 려움을 보였다. 반면 경심도 난독 집단의 경우 종성 자소의 유무보 다는 종성 자소의 개수에 따른 수행력 차이를 보였다. 즉종성 자소 가 없는 단어와 종성 자소가 1 개인 단어에서는 비슷한 어려움을 보 였으나(CV-CV: 74\%, CV-CVC: 78.33\%, CVC-CV: 73.33\%), 종성 자소 개수가 2 개인 단어(예: 방팀, 청군)에서는 수행이 현저히 낮아 졌다(CVC-CVC: 60\%).

단어구조에 따른 결과를 동일한 검사를 사용한 Yang과 Pae (2018) 의 연구결과와 비교하였을 때, 선행연구의 대상자와 유사한 해독 능력을 가진 경심도 난독 집단은 종성 자소의 개수가 증가함에 따 라 해독에 어려움을 보이는 동일한 결과를 보였다. 그러나 심도 난 독 집단의 결과는 선행연구와 달리 종성 자소가 포함됨에 따라 해 독에 어려움이 나타났다. 이러한 결과는 발달성 난독 집단이라는 공통점을 가질지라도 해독 수행력에 따라 단어구조에 따른 읽기의 강약점이 달라질 수 있음을 의미한다. 그러므로 발달성 난독 아동 의 읽기능력을 평가하거나 중재할 때 제시되는 단어의 구조를 고려 해야 함을 시사한다. 더 나아가 두 집단에서 모두 공통적으로 나타 난 특징이 있었는데, 단어구조가 복잡해짐에 따라 CV-CV 구조에 서는 나타나지 않았던 초성 자소와 중성 자소의 읽기 오류가 나타

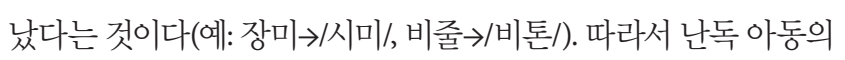
평가 및 중재 시, 동일한 자소라도 단어구조의 복잡성에 따라 수행 이 달라질 수 있으므로 다양한 단어구조에서 읽기 수행을 확인하
는 것이 필요할 것으로 보인다.

해독 수행력과 음절 내 위치에 따른 읽기 특성도 다른 양상을 보 였다. 구성소 이론(grain size theory)에 따르면, 읽기 습득에서 음 운적 표상을 구성하는 단위의 크기(grain size)가 중요하다고 하였 다(Ziegler \& Goswami, 2005). 이러한 심리언어학적인 구성소 단위 (grain size)는 언어의 철자법(orthographic) 깊이에 따라 달라지며, 영어, 중국어, 독일어와 같이 다양한 언어권에서의 구성소 단위 분류 가 다르다는 연구들이 있다(Schmalz, Robidoux, Castles, Coltheart, \& Marinus, 2017; O'Brien, Mohamed, Yussof, \& Ng, 2019). 영어는 음절 단위에서 두운과 각운(onset rime), 음소 단위로 발달하는 반 면, 표층표기체계를 가진 한국어는 음절 단위에서 음절체와 종성 (body coda), 음소 단위로 음운적 표상이 나누어진다고 한다(Kim, 2007; Kim \& Cho, 2001). 특히 3-5세 일반 아동의 초기 읽기능력을 살펴본 연구에서 한국 아동의 경우, 영어권 아동들과 달리 발달적 으로 음절 단위의 읽기 특성을 보인다고 하였다(Kim, Lombardino, Park, \& Lee, 2008). 본 연구결과에서 두 집단의 읽기 수행을 음절 내 위치로 분석한 결과, 초성 자소 위치에서 경심도 난독 집단은 읽 기 정확률 $93.13(\%)$, 심도 난독 집단은 읽기 정확률 90 (\%)로 유사 한 수행을 보였다 $(t=-1.387, p=.182)$. 반면 중성 자소 위치에서 경 심도 난독 집단은 97 (\%), 심도 난독 집단은 89.87 (\%)의 읽기 정확 률을 보였으며, 종성 자소 위치에서는 경심도 난독 집단은 86.88 (\%), 심도 난독 집단은 70.22 (\%)의 읽기 정확률이 나타나 중성과 종성 자소 위치에서 두 집단 간 차이가 유의미하였다 $(t=-2.944$, $t=-3.682, p<.05)$. 따라서 심도 난독 집단은 한국어의 주요 구성소 단위인 음절체와 종성 자소에서 음절체 내의 음절핵(중성 자소)과 종성 자소에 모두 어려움을 보이며, 경심도 난독 집단은 종성 자소 에 어려움을 보이는 것을 알 수 있었다.

중성 자소 위치에서의 읽기 수행은 경심도 난독 집단보다 심도 난독 집단에서 어려움이 두드러졌다. 다수의 선행연구들은 한국어 에서 음절체와종성(body coda)에 대한 중요성을 언급하였으나, 음 절체를 구성하는 음절핵인 중성 자소에 대한 중요성은 많이 다루 어지지 않았다. 본 연구결과에서는 심도 난독 집단이 중성 자소 읽 기에 어려움을 보임을 확인하였다. 이는 중성 자소가 난독 아동의 읽기 심도에 따른 단어 읽기 특성을 보여줄 수 있음을 시사한다. 따 라서 음절체를 구성하는 음절핵(syllable medial grapheme) 읽기에 대한 수행력을 확인하는 것은 발달성 난독 아동의 읽기 어려움 정 도를 확인하는데 유용할수 있다.

종성 자소 위치의 읽기에서는 두 집단 모두 종성 자소에 대한 정 확률이 낮으며, 심도 난독 집단의 경우 경심도 난독 집단보다 더 낮 은 정확률을 보이는 것으로 나타났다. 이는 발달성 난독 아동이 종 
성 자소 위치에서 읽기 어려움이 두드러진다는 선행연구(Yang \& Pae, 2018; Won et al., 2020) 결과와 일치하였다. 본 연구에서는 더 나아가 추가로 심도 난독 집단과 경심도 난독 집단이 종성 자소 위 치에서 보인 오류 유형을 분석하였다. 경심도 난독 집단에서는 종 성 자소를 대치하는 오류가 주를 이루었으나, 심도 난독 집단에서 는 종성 자소를 생략하는 오류가 주로 나타났다. 즉 단어 읽기능력 의 심도(severity)에 따라 정확률뿐만 아니라 오류 유형에서도 다른 특성이 나타남을 확인할 수 있었다.

종합해보았을 때, 심도 난독 집단과 경심도 난독 집단 모두 동일 하게 초등학교 1학년의 발달성 난독 아동에 속함에도 불구하고 단 어 읽기 수행 정도에 따라 의미 유무, 단어구조, 음절 내 위치에 따 른 서로 다른 읽기 특성이 나타났다. 특히 유사한 시기에 동일한 검 사도구를 사용하여 자소-음소 일치형 단어 해독 특성을 살펴본 선 행연구(Jeong, 2017; Kim, 2015; Kim \& Pae, 2007, 2011; Song et al., 2016; Yoon et al., 2011)에서, 일반 집단의 경우 해독 정확률이 천정 점에 도달한 결과와 비교하면 본 연구의 발달성 난독 아이들이 아 직 학년 수준에 적절한 단어 읽기를 성취하지 못한 것으로 보인다. 이는 교육부(2015)에서 발표한 '한글 책임교육'에 따라 초등학교 1 학년 1학기에 약 68 시간에 걸쳐 중성에서 초성 자음, 종성 자음까 지 아우르는 집중적인 한글 교육이(National Education Training Institute, 2019) 음운론적 결함을 갖는 발달성 난독 아동에게는 충 분하지 않는 것으로 해석된다. 따라서 발달성 난독 아동 개인의 강 점과 약점에 근거한 개별화된 읽기 중재가 반드시 필요하다(Dinishak, 2016; Kim \& Jung, 2019; Lyon et al., 2003; Pae et al., 2016; Won et al., 2020; Yang \& Pae, 2018).

따라서 발달성 난독 아동을 대상으로 읽기 중재를 실시할 경우 아동의 읽기 수행을 면밀히 관찰하여 어떤 단어구조와 음절 내 위 치에서 읽기 오류가 나타나는지 확인하고 아동의 읽기 수행 수준 에 근거한 중재를 제공하는 것이 가장 중요하다. 비록 본 연구에서 는 난독 아동의 읽기 수행을 두 집단(severe, less severe)으로 나누 어 비교하였지만, 두 집단은 단어의 의미 유무, 단어구조의 복잡성, 음절 내 위치에 따라 영향을 받는 양상이 다르게 나타났다. 그러므 로 아동 개개인의 해독 수행 수준을 우선 파악하는 것이 중요할 것 으로 보인다. 또한 읽기 중재 접근면에서 보았을 때, 심도 난독 집단 의 경우, 음절 단위의 읽기부터 시도하거나 종성 자소 유무에 따른 의미 차이를 활용하여 종성 자소 인식에 대한 지도부터 시도하고, 경심도 난독 집단 수준 아동의 경우, 종성 자소의 개수를 조절해주 어 읽기 자료를 제공해주는 것이 필요할 것으로 보인다. 특히 두 집 단 모두 의미 단어뿐만 아니라 무의미 단어 내에서도 자소와 음소 를 대응하여 읽는 연습이 충분히 필요할 것이다.
본 연구는 발달성 난독 초등 1 학년 아동의 해독 수행력과 단어의 의미 유무에 따른 해독 특성, 단어구조에 따른 해독 특성, 음절 내 위치에 따른 해독 특성을 알아보고자 하였다. 본 연구에서는 난독 아동의 읽기 수행 심도에 따라 한국어의 구성소 단위를 중심으로 읽기 특성을 살펴볼 수 있었다. 하지만 일반적인 읽기 발달을 보이 면서 해독 수준이 일치된 일반 비교 집단이 포함되지 않아 일반 아 동과는 다른 발달성 난독 아동만이 보이는 읽기 특성을 살펴보지 못했다는 점에 제한점이 있다. 따라서 이를 보완하여 해독 수준이 동일한 더 어린 연령의 일반 집단에서는 구성소 단위에 따라 읽기 수행이 어떠한지 살펴보고, 발달성 난독 아동과의 해독 오류 특성 에 어떠한 차이가 있는지 살펴보는 후속연구가 요구된다. 또한 본 연구에 참여한 발달성 난독 아동 모두 무의미 단어 읽기에 어려움 을 보였으며, 연구결과에 대해 다수의 선행연구를 바탕으로 음운 론적 결함으로 인한 결과임을 추측할 수 있었다. 따라서 이후 발달 성 난독 아동을 읽기 수행력에 따라 나눈 후 음운처리능력을 함께 파악하여 무의미 단어 읽기와의 관련성을 보는 것이 필요할 것이 다. 마지막으로 발달성 난독 아동의 읽기 수행력에 따른 읽기 오류 와 함께 철자 오류 양상도 함께 확인하여 난독 아동의 읽기 수행 심 도에 따라 읽기와 철자 특성을 함께 살펴보는 후속연구가 필요할 것으로 보인다.

\section{REFERENCES}

American Psychiatric Association. (2013). Diagnostic and statistical manual of mental disorders; DSM-5 (5th ed.). Washington, DC: Author.

Byun, C. S., \& Kim, G. S. (2008). The effects of teaching phonological awareness on word recognition in children with learning disabilities. The Journal of Special Education: Theory and Practice, 9(3), 331-351.

Catts, H. W. (1996). Defining dyslexia as a developmental language disorder: an expanded view. Topics in Language Disorders, 16(2), 14-29.

Chall, J. S. (1983). Stages of reading development. New York: McGraw-Hill.

Chan, D. W., Ho, C. S. H., Tsang, S. M., Lee, S. H., \& Chung, K. K. (2007). Prevalence, gender ratio and gender differences in reading-related cognitive abilities among Chinese children with dyslexia in Hong Kong. Educational Studies, 33(2), 249-265.

Dinishak, J. (2016). The deficit view and its critics. Disability Studies Quarter$l y, 36(4)$.

Frith, U., Wimmer, H., \& Landerl, K. (1998). Differences in phonological recoding in German-and English-speaking children. Scientific Studies of Reading, 2(1), 31-54. 
Gough, P. B., \& Tunmer, W. E. (1986). Decoding, reading, and reading disability. Remedial and Special Education, 7(1), 6-10.

Hogan, T. P. (2018). Five ways speech-language pathologists can positively impact children with dyslexia. Language, Speech and Hearing Services in Schools, 49(4), 902-905.

Jeong, J. (2014). An examination of first graders' consonant-vowel naming, word recognition, and reading fluency. The Journal of Elementary Education, 27(3), 119-136.

Jeong, J. (2017). An analysis of first graders` features in decoding words and nonwords: based on word types and reading levels. The Korean Society for Child Education, 26(1), 341-357.

Kim, A., Yoo, H., \& Kim, U. (2010). The relationship of phonological awareness, rapid naming, letter knowledge, short-term memory, and working memory to Hangul word recognition abilities. Korean Journal of Special Education, 45(1), 247-267.

Kim, H. J., \& Cho, J. R. (2001). Phonological awareness, visual perception, and reading of Hangul in preschool children. Korean Journal of Developmental Psychology, 14(2), 15-28.

Kim, H. J., \& Kim, D. (2009). The developmental pattern of phonological processing and early reading abilities for preschool children. Proceedings of the 2009 Conference the Korean Society of Special Education, 123-147.

Kim, H. S. (2010) Research of the vocabulary of textbooks for selecting vocabulary of Korean education-analysis on elementary school textbooks. The Journal of Korean Language and Literature Education, 47, 63-90.

Kim, J. H., \& Jung, P. G. (2019). Effects of professional development on individualized reading intervention on decoding and reading fluency for students struggling with reading. Journal of Early Childhood Education, 18(1), 173-196.

Kim, M. B., \& Pae, S. (2007). Word recognition and phonological awareness of kindergartener, second and fourth graders. Journal of Speech-Language \& Hearing Disorder, 16(2), 89-107.

Kim, M. B., \& Pae, S. (2014). Word reading ability and predictors of word reading in poor word readers of Korean children. Journal of Learner-Centered Curriculum and Instruction, 14(9), 329-343.

Kim, M. B., \& Pae, S. (2011). The decoding development of Korean children in word reading. Korean Journal of Communication \& Disorders, 16(2), 143153.

Kim, Y. S. (2007). Phonological awareness and literacy skills in Korean: an examination of the unique role of body-coda units. Applied Psycholinguistics, 28(1), 69 .
Kim, Y. T., Lombardino, L. J., Park, E., \& Lee, S. H. (2008). Early literacy development in Korean children aged three to five years. Korean Journal of Communication \& Disorders, 13(3), 418-437.

Kim, Y. W. (2015). A comparison of word recognition and spelling skills between students with reading disabilities and without disabilities. The Journal of Special Education: Theory and Practice, 16(4), 363-386.

Landerl, K., Wimmer, H., \& Frith, U. (1997). The impact of orthographic consistency on dyslexia: a German-English comparison. Cognition, 63(3), 315-334.

Lee, E. J., \& Kim, Y. T. (2020). Identifying developmental dyslexia in 9 Korean elementary school students at risk for dyslexia. Communication Sciences e Disorders, 25(3), 546-580.

Lee, K. (1998). The internal structure of Korean syllables: rhyme or body?. Korean Journal of Experimental Cognitive Psychology, 10(1), 67-83.

Lyon, G. R., Shaywitz, S. E., \& Shaywitz, B. A. (2003). A definition of dyslexia. Annals of Dyslexia, 53(1), 1-14.

Miles, T. R. (2004). Some problems in determining the prevalence of dyslexia. Electronic Journal of Research in Educational Psychology, 2(2), 5-12.

Ministry of Education. (2015). Responsible Korean language education. Retrieved from https://www.moe.go.kr/boardCnts/view.do?boardID=316\&l ev $=0 \&$ statusYN=C\&s=moe\&m=0302\&opType $=\mathrm{N} \&$ boardSeq $=62381$.

O’Brien, B. A., Mohamed, M. B. H., Yussof, N. T., \& Ng, S. C. (2019). The phonological awareness relation to early reading in English for three groups of simultaneous bilingual children. Reading and Writing, 32(4), 909-937.

Pae, S., Kim, M. B., Yoon, H. J., \& Jang, S. (2015). Korean language based reading assessment (KOLRA). Seoul: Hakjisa.

Pae, S., Seol, A. Y., Yang, Y., Sim, Y., Hwang, S., \& Shin, G. (2016). Individualized decoding and reading fluency program for elementary school children with developmental dyslexia. Proceedings of the 2017 Conference the Korean Speech-Language \& Hearing Association, 171-173.

Pae, S., Shin, G., \& Seol, A. (2017). Developmental characteristics of word decoding and text reading fluency among Korean children with developmental dyslexia. Communication Sciences \& Disorders, 22(2), 272-283.

Park, H. (2014). Korean version of comprehensive test of nonverbal intelligence second edition (K-CTONI-2). Seoul: Mindpress.

Peterson, R. L., \& Pennington, B. F. (2015). Developmental dyslexia. Annual Review of Clinical Psychology, 11, 283-307.

Schmalz, X., Robidoux, S., Castles, A., Coltheart, M., \& Marinus, E. (2017). German and English bodies: No evidence for cross-linguistic differences in preferred orthographic grain size. Collabra: Psychology, 3(1), 1-21. 
Snowling, M. (1998). Dyslexia as a phonological deficit: evidence and implications. Child Psychology and Psychiatry Review, 3(1), 4-11.

Song, Y., Shin, G. Y., \& Pae, S. (2016). Decoding and spelling abilities of Korean first and second graders with and without language reading difficulties. Journal of Speech-Language \& Hearing Disorders, 25(4), 97-107.

Torgesen, J. K. (2005). Recent discoveries from research on remedial interventions for children with dyslexia. In M. Snowling \& C. Hulme (Eds.), The science of reading: a handbook (pp. 521-537). Oxford: Blackwell Publishers.

Wagner, R. K., \& Torgesen, J. K. (1987). The nature of phonological processing and its causal role in the acquisition of reading skills. Psychological Bulletin, 101(2), 192-212.

Won, H., Seol, A. Y., Jang, W., Lee, J., \& Pae, S. (2020). Individualized Korean phonics intervention for 1st and 2nd graders at risk of developmental dyslexia. Journal of Learner-Centered Curriculum and Instruction, 21(2), 27-
45.

Yang, Y., \& Pae, S. (2018). Korean first graders' word decoding skills, phonological awareness, rapid automatized naming, and letter knowledge with/ without developmental dyslexia. Phonetics and Speech Sciences, 10(2), 5160.

Yoon, H., Kim, M. B., \& Pae, S. (2011). The decoding skills of school-aged children with poor reading skills. Korean Journal of Communication \& Disorders, 16(4), 582-596.

Ziegler, J. C., \& Goswami, U. (2005). Reading acquisition, developmental dyslexia, and skilled reading across languages: a psycholinguistic grain size theory. Psychological Bulletin, 131(1), 3-29.

Ziegler, J. C., Castel, C., Pech-Georgel, C., George, F., Alario, F. X., \& Perry, C. (2008). Developmental dyslexia and the dual route model of reading: simulating individual differences and subtypes. Cognition, 107(1), 151-178. 
Appendix 1. 대상자 반응 예시

\begin{tabular}{|c|c|c|c|c|c|c|c|c|c|}
\hline \multirow{3}{*}{ Target word } & & \multicolumn{4}{|c|}{ Severe dyslexia group } & \multicolumn{4}{|c|}{ Less severe dyslexia group } \\
\hline & & \multirow{2}{*}{ Response } & \multicolumn{3}{|c|}{ Scoring } & \multirow{2}{*}{ Response } & \multicolumn{3}{|c|}{ Scoring } \\
\hline & & & SIG & SMG & SFG & & SIG & SMG & SFG \\
\hline \multicolumn{10}{|l|}{ Word (18) } \\
\hline CV-CV & 소리 & + & $2 / 2$ & $2 / 2$ & - & + & $2 / 2$ & $2 / 2$ & - \\
\hline CV-CVC & 시장 & + & $2 / 2$ & $2 / 2$ & $1 / 1$ & + & $2 / 2$ & $2 / 2$ & $1 / 1$ \\
\hline CVC-CV & 장미 & 점미 & $2 / 2$ & $1 / 2$ & $0 / 1$ & + & $2 / 2$ & $2 / 2$ & $1 / 1$ \\
\hline CVC-CVC & 발톱 & 발테 & $2 / 2$ & $1 / 2$ & $1 / 2$ & 말토 & $1 / 2$ & $2 / 2$ & $1 / 2$ \\
\hline \multicolumn{10}{|c|}{ Non word (18) } \\
\hline CV-CV & 고드 & 고버 & $1 / 2$ & $1 / 2$ & - & 고트 & $1 / 2$ & $2 / 2$ & - \\
\hline CV-CVC & 조번 & 조버 & $2 / 2$ & $2 / 2$ & $0 / 1$ & 조변 & $2 / 2$ & $1 / 2$ & $1 / 1$ \\
\hline CVC-CV & 벙미 & 버미 & $2 / 2$ & $2 / 2$ & $0 / 1$ & 멍미 & $1 / 2$ & $2 / 2$ & $1 / 1$ \\
\hline CVC-CVC & 둔촐 & 부철 & $1 / 2$ & $1 / 2$ & $1 / 2$ & 두촐 & $2 / 2$ & $2 / 2$ & $1 / 2$ \\
\hline
\end{tabular}

Appendix 2. 음절 내 위치 별 분석 예시

\begin{tabular}{|c|c|c|c|}
\hline \multirow{2}{*}{ Target word } & \multicolumn{3}{|c|}{ Analysis example } \\
\hline & SIG & SMG & SFG \\
\hline 가더 & \urcorner,$\sqsubset$ & t. & \\
\hline 수젤 & 人, 2 & $T, \|$ & z \\
\hline 방팀 & $\forall, E$ & ト. I & 0,0 \\
\hline
\end{tabular}

SIG = Syllable Initial Grapheme; SMG = Syllable Medial Grapheme; SFG = Syllable Final Grapheme. 


\section{국문초록}

\section{발달성 난독 초등 1학년생의 읽기 심도와 단어 및 음절구조에 따른 단어 해독력 유해림 ${ }^{1}$ 원효은 1 배소영2 \\ '한림대학교 일반대학원 언어병리청각학과, ${ }^{2}$ 한림대학교 언어청각학부, 청각언어연구소}

배경 및 목적: 본 연구는 한국 발달성 난독 초등 1 학년 집단을 읽기능력 심도로 나누어 단어의 의미 유무, 단어구조 및 음절 내 위치에 따른 읽기 특성을 알아보고자 하였다. 방법: 한국 초등 1 학년 발달성 난독 아동 20 명에게 한국어 읽기검사(KOLRA)의 하위 검사인 단 어 해독 과제를 실시하였다. 대상 아동의 경우, 듣기 이해력과 지능 검사에서 정상 범주에 속하였음에도 심도의 단어 읽기능력을 가진 아 동이었다. 단어 해독능력에 따라 심도 집단과 경심도 집단으로 나누었으며, 자소-음소 일치형 단어를 의미 유무, 단어구조, 음절 내 위치 에 따른 집단차이를 비교하였다. 결과: 심도 집단과 경심도 집단 모두 의미 단어 읽기와 무의미 단어 읽기 사이의 수행 차이가 나타났다. 두 집단은 모두 단어 내 종성 자소 해독에 어려움을 보였는데, 심도 집단의 경우 종성 자소의 개수가 2 개일 때 현저한 해독의 어려움이 나타났다. 또한 두 집단은 초성 자소 읽기에 유사한 수행을 보였으나, 심도 집단의 경우 경심도 집단에 비해 중성 자소, 종성 자소 읽기에 더욱 어려움을 보였다. 논의 및 결론: 한국 발달성 난독 초등 1 학년 아동들은 단어와 음절구조를 고려한 단어 해독 지원이 신속히 이루 어져야 할 것으로 보인다. 따라서 어휘경로를 활용한 의미 단어 읽기뿐만 아니라 중성 및 종성 자소의 구성소 단위(grain size)를 고려한 무의미 단어를 통해 비어휘경로를 활성화시킴으로써 심도의 난독증을 가진 한국 아동의 단어 해독 능력을 촉진시킬 수 있을 것이다.

핵심어: 한국어, 발달성 난독증, 해독 심도 집단, 음절 종성 해독 구성소

\section{참고문헌}

교육부 (2015). 한글 책임교육. 서울: 교육부.

김미배, 배소영 (2007). 유치원, 초등 2, 4학년의 단어재인 및 음운인식 능력. 언어치료연구, 16(2), 89-107.

김미배, 배소영 (2011). 단어읽기에서의 초등학생 음운해독력 발달. 언어청각장애연구, 16(2), 143-153.

김미배, 배소영 (2014). 음운해독부진아동의 단어읽기능력과 예측변인. 학습자중심교과교육연구, 14(9), 329-343.

김애화, 유현실, 김의정 (2010). 음운인식, 빠른 자동 이름대기, 자모지식, 단기기억, 작동기억과 한글 단어인지 능력 간의 관련성에 관한 연구: 읽기장

애조기선별을 위한 기초연구. 특수교육학연구, 45(1),247-267.

김영태, Lombardino, 박은혜, 이소현 (2008). 한국형 진단 프로토콜을 이용한 3- 5 세 한국 아동의 초기읽기 발달연구. 언어청각장애연구, 13(3), 418-

437.

김용욱 (2015). 읽기장애학생과 일반학생의 단어인지와 철자법 특성 비교. 특수교육 저널: 이론과 실천, 16(4),363-386.

김중훈, 정평강 (2019). 개별화 읽기교수를 위한 전문성개발 프로그램이 읽기부진 아동의 해독 및 읽기 유창성에 미치는 효과. 특수교육, 18(1), 173-

196.

김한샘 (2010). 국어 교육용 어휘 선정을 위한 교과서 어휘 조사 연구: 초등학교 교과서 어휘 분석. 국어교육연구, 47, 63-90.

김현자, 조증열 (2001). 학령전 아동에서 음운인식, 시각지각 및 한글 읽기와의 관계. 한국심리학회지: 발달, 14(2), 15-28.

김희진, 김동일 (2009). 읽기 학습장애 위험아동 조기선별을 위한음운처리과정과 초기읽기의 발달패턴 분석. 한국특수교육학회 학술대회, 123-147. 배소영, 김미배, 윤효진, 장승민 (2015). 한국어 읽기검사(KOLRA). 서울: 학지사.

배소영, 설아영, 양유나, 심유미, 황수진, 신가영 (2016). 고위험 난독군 아동을 위한 개별 맞춤형 한글 해독 프로그램 개발. 한국언어치료학회 학술발 표대회 논문집, 171-173.

배소영, 신가영, 설아영 (2017). 한국 발달성 난독 학생의 해독 및 읽기유창성 발달 특성. Communication Sciences \& Disorders, 22(2), 272-283.

박혜원 (2014). 한국비언어지능검사(K-CTONI-2). 서울: 마인드프레스. 
변찬석, 김길순 (2008). 음운인식 훈련이 학습장애아의 단어재인에 미치는 효과. 특수교육 저널: 이론과 실천, 9(3), 331-351.

송엽, 신가영, 배소영 (2016). 초등학교 1, 2학년 언어.읽기부진아동과 정상아동의 해독 및 철자 특성. 언어치료연구, 25(4), 97-107.

이광오 (1998). 한국어 음절의 내부구조: 각운인가음절체인. 한국심리학회지: 인지 및 생물, 10(1), 67-83.

이은주, 김영태 (2020). 발달성 난독증 진단: 난독증 의심 증상을 보이는 한국 초등학생 9명을 대상으로. Communication Sciences \& Disorders,

25(3), 546-580.

양유나, 배소영 (2018). 초등 1학년 발달성 난독 아동의 단어 해독, 음운인식, 빠른 이름대기, 자소 지식. 말소리와음성과학, 10(2), 51-60.

원효은, 설아영, 장우정, 이정민, 배소영 (2020). 초등 1,2 학년 난독 고위험군 아동에 대한 개별화된 파닉스프로그램 중재효과. 학습자중심교과교육연

구, 21(2), 27-45.

윤효진, 김미배, 배소영 (2011). 읽기부진아동의 해독특성. 언어청각장애연구, 16(4), 582-596.

정종성 (2014). 초등학교 입학 아동의 자모 인식, 단어 해독, 읽기 유창성 수행 수준 탐색. 초등교육연구, 27(3), 119-136.

정종성 (2017). 초등학교 1학년 학생의 단어 읽기 특성 분석: 단어 유형, 읽기 수준을 중심으로. 아동교육, 26(1), 341-357.

\section{ORCID}

유해림(제1저자, 대학원생 https://orcid.org/0000-0002-7449-9823); 원효은(공동저자, 대학원생 https://orcid.org/0000-0001-5782-3452);

배소영(교신저자, 교수 https://orcid.org/0000-0001-6577-0880) 